\title{
PELATIHAN EKSPLORASI JERAMI MENJADI KARYA SENI PATUNG DI MARTAPURA OGAN KOMERING ULU TIMUR SUMATERA SELATAN
}

\author{
Husni Mubarat, Mukhsin Ilhaq
}

\author{
Desain Komunikasi Visual, Ilmu Pemerintahan dan Budaya \\ Universitas Indo Global Mandiri Palembang \\ Sendratasik, Fakultas Keguruan dan Ilmu Kependidikan, \\ Universitas PGRI Palembang \\ Jl. Jend. Sudirman No. 629 KM. 4,5 Kota Palembang \\ Jl. Jend. Ahmad Yani, Lr. Gotong Royong 9/10 Ulu, Seberang Ulu I Kota Palembang \\ husni_dkv@uigm.ac.id, ilhaque@gmail.com
}

\begin{abstract}
ABSTRAK
Pelatihan patung jerami di Ogan Komering Ulu (OKU) Timur merupakan suatu upaya memberikan edukasi dan pengalaman terhadap masyarakat. Di mana diketahui selama ini masyarakat belum memiliki kreativitas dalam mengeksplorasi jerami menjadi karya seni patung. Pelatihan ini merupakan kegiatan festival jerami dengan tema "Sibiduk Sehaluan" yang mana karya-karya patung jerami tersebut dipamerankan selama kegiatan itu berlangsung. Kegiatan ini bertujuan untuk memberi pengetahuan, keterampilan, dan kreativitas tentang proses pembuatan patung Jerami, mulai dari hal-hal yang bersifat teknis, desain, hingga konseptual. Metode pelaksanaan terdiridari pemaparan materi,demonstrasi, dan bimbingan. Adapun hasil pelatihan selama kegiatan tersebut berlangsung di antaranya adalah; peserta dapat membuat konsep karya seni patung jerami, mengetahui proses dan teknik pembuatan kerangka patung, mendapatkan pengalaman dan pengetahuan cara membuat sketsa dan penyajian karya serta mendapatkan pengetahuan tentang kegiatan pelaksanaan pameran.
\end{abstract}

Kata Kunci: Eksplorasi; Jerami; Patung; Martapura. 


\section{Jurnal Batoboh, Vol 4, No1, Maret 2019 \\ Husni Mubarat, Mukhsin Ilhaq}

\section{PENDAHULUAN}

Ogan Komering Ulu (OKU) Timur merupakan salah satu Kabupaten di Provinsi Sumatera Selatan yang merupakan perbatasan dengan Provinsi Lampung. Potensi yang dimiliki Kabupaten OKU Timur cukup banyak, mulai dari pertanian hingga budaya dan seni kerajinannya. Untuk pertanian sendiri OKU Timur disebut sebagai salah satu lumbung padi nasional. Oleh karenanya daerah ini dapat disebut sebagai lahan pertanian sawah yang produktif, khususnya di provinsi Sumatera Selatan. Melihat potensi tersebut, beberapa pemuda dan wartawan bekerjasama dengan pemerintah kabupaten mencoba merumuskan bagaimana keunggulan pertanian padi dan sawah tersebut dibuatkan ivent wisata dengan Tema Festival Jerami OKU Timur Sebiduk Sehaluan.

Festival Jerami ini pertamakali diadakan di Kabupaten OKU Timur, bahkan dapat dikatakan untuk di Sumatera, khususnya di Sumatera
Selatan ini satu-satunya festival Jerami yang pernah dilaksanakan. Ivent ini juga melibatkan kaum akademisi dan praktisi untuk merumuskan konsep Hal|45 festival tersebut, yaitu dikemas dalam wujud pameran akbar patung Jerami dengan tema "Sebiduk Sehaluan". Ivent tersebut tidak hanya memperkenalkan dan memperkuat OKU timur sebagai salah satu daerah lumbung padi nasional, namun juga merupakan ajang memperkenalkan kearifan budaya lokal yang ada di daerah tersebut, pertanian, budaya, maupun keseniannya.

Festival Jerami yang diadakan untuk pertama kalinya mendapat respon yang poitif baik dari pemerintah daerah, provinsi hingga tingkat nasional yang dalam hal ini dihadiri oleh Kementrian Pariwisata (KEMENPAR). Untuk perwakilan provinsi sendiri dihadiri langsung oleh Gubernur Sumatera Selatan yang sekali gus membuka acara tersebut (ketika itu masih dijabat oleh H. Alex Noerdin). Kemeriahan ivent tersebut juga tidak terlepas dari ivent Internasional yaitu 


\section{Jurnal Batoboh, Vol 4, No1, Maret 2019 \\ Husni Mubarat, Mukhsin Ilhaq}

ASEAN GAMES yang diselenggarakan di Palembang dan Jakarta, sehingga ivent ini juga sekaligus untuk medukung ivent Asean Games tersebut.

Kartika (2004: 27) dalam buku seni rupa modern menjelaskan bahwa: Masyarakat dan seni memang berbeda dalam pengertiannya, tetapi sebenarnya keduanya memiliki interaksi psikis. Di satu pihak dominasi subyektivitas seniman dalam mecari bentuk penyesuaian dengan lingkungan masyarakatnya, di lain pihak masyarakat sendiri merupakan satu organisasi atau satu kesatuan yang memiliki bentuk-bentuk penyesuaian secara internal dan eksternal.

Patung jerami sebagai center of interest atau pusat perhatian digarap langsung oleh pemuda dari berbagai Kecamatan di OKU Timur. Selain itu karya-karya patung dari jerami tersebut juga melibatkan setiap instansi dan lembaga pendidikan agar berpartisipasi untuk menyumbangkan karya seni Patung Jerami. Kreatifitas tersebut melahirkan ragam bentuk dan anatomi patung Jerami mulai dari bentuk figur manusia (petani), hewan, buah-buahan dan hasil pertanian hingga karya seni patung yang ekspresif. Ragam Hal|46 kreatifitas patung jerami tersebut membawa festival ini mendapat rekor MURI sebagai Festival Patung Jerami terbesar di Indonesia. Hal yang tidak kalah menariknya juga adalah pada sesi pembukaan yang disambut dengan tari massal dengan koreografernya adalah Doni Angga. Tari ini melibatkan lima ratusan siswa/i SLTP yang ada di Kab. OKU Timur.

Dalam kegiatan ini, penulis tidak hanya sebagai bagian dari konseptor acara, namun juga memberikan pelatihan dan keterampilan terhadap pemuda di sekitarnya mengenai pembuatan kerangka dan bentukbentuk anatomi patung jerami tersebut. Pelatihan tersebut merupakan sebuah proses transfer ilmu pengetahuan seni rupa terhadap pemuda. Melalui keterampilan teknis dan konsep yang diberikan itu diharapkan pemuda di Kab. OKU Timur mendapatkan pengalaman menggarap ivent dan 


\section{Jurnal Batoboh, Vol 4, No1, Maret 2019 \\ Husni Mubarat, Mukhsin Ilhaq}

berkarya seni rupa (seni patung). Dalam kegiatan pelatihan keterampilan pembuatan patung Jerami ini melibatkan banyak Tim mulai dari konseptor, desainer, hingga praktisi sehingga hasil yang diharapkan dapat tercapai. Hajar Pamadhi (2012) dalam Irawan, ed. (2017: 148) memberikan inspirasi mengenai pengertian seni sebagai media untuk mengungkapkan ide dan gagasan karena setiap manusia ingin berbicara dan mengungkapkan imajinasinya dalam konteks kebutuhan mengutarakan pendapat. Relevansinya adalah seni sebagai media untuk mengembangkan kreativitas.

Sebagai tim konseptor dari kaum akademis tentunya pengabdian ini merupakan bagian dari tanggung jawab terhadap masyarakat sebagaimana yang tercantum dalam Undang-Undang Nomor 20 Tahun 2003 tentang Sistem Pendidikan Nasional menyebutkan bahwa perguruan tinggi berkewajiban menyelenggarakan pendidikan, penelitian, dan pengabdian kepada masyarakat (Pasal 20 Ayat 2). Jacobus Ranjabar (2006: 20) menjelaskan bahwa masyarakat adalah orang atau manusia yang hidup bersama yang menghasilkan kebudayaan, keduanya tak dapat Hal|47 dipisahkan dan selamanya merupakan dwitunggal. Tak ada masyarakat yang tidak mempunyai kebudayaan dan sebaliknya, tak ada kebudayaan tanpa masyarakat .

Sebagai bagian dari kaum akademisi tentu memiliki kewajiban dan berkomitmen untuk melaksanakan pengabdian terhadap masyarakat secara berkala. Hal ini bertujuan untuk memberikan wawasan dan mengembangkan keterampilan bagi masyarakat di Kota Palembang, dan Sumatera Selatan pada umumnya. Salah satu upaya tersebut adalah Pelatihan pembuatan patung jerami pada ivent Festival Jerami "Sebiduk Sehaluan" di OKU Timur.

Keterampilan ini tentunya diharapkan dapat memberi wawasan terhadap peserta dalam hal ini adalah pemuda di Kab. OKU Timur, sehingga nantinya dapat memiliki pengalaman untuk membuat karya seni patung 


\section{Jurnal Batoboh, Vol 4, No1, Maret 2019 \\ Husni Mubarat, Mukhsin Ilhaq}

jerami pada ivent berikutnya. Dengan demikian, komitmen Perguruan Tinggi ataupun Institusi Pendidikan Tinggi dalam upaya mengimplentasikan tridarma perguruan tinggi (pengabdian masyarakat) akan selalu dilakukan. Dalam hal ini adalah pembangunan terhadap Sumber Daya Manusia (SDM) yang memiliki keterampilan di bidang seni dan desain.

\section{Tujuan Kegiatan}

Adapun tujuan kegiatan pengabdian ini adalah:

1. Memberikan pengetahuan dan pemahaman kepada pemuda OKU Timur bagaimana menungkan konsep pada media seni patung.

2. Melatih keterampilan dan kreativitas pembuatan karya seni patung dengan bahan jerami

3. Memberikan pengetahuan teknis terhadap peserta pelatihan, bagaimana membuat rangka dan bentuk karya patung jerami.

4. Memberikan pengalaman dan dorongan kepada peserta pelatihan dalam mengelola pameran dan acara festival jerami OKU Timur, sehingga ivent tersebut dapat dijadikan ivent tahunan OKU Timur.

\section{Metode Pelaksanaan}

Metode dapat diartikan sebagai sebuah cara atau strategi atau jalan yang harus dilalui untuk mencapai suatu tujuan. Dalam kamus bahasa Indonesia dijelaskan bahwa metode adalah "cara yang telah teratur dan terpikir baik-baik untuk mencapai suatu maksud" (WJS Poerwadarminta, 1976: 648). Adapun metode pelaksanaan dalam pengabdian Pelatihan pembuatan patung jerami di OKU Timur adalah:

1) Menyusun Materi

Materi yang disusun merupakan pengetahuan dan wawasan mengenai pengertian seni patung, bentuk, bahan dan teknik pembuatan seni patung. Selain itu materi yang juga disusun adalah pemahaman dan uraian tentang bagaimana proses layout pameran 


\section{Jurnal Batoboh, Vol 4, No1, Maret 2019 \\ Husni Mubarat, Mukhsin Ilhaq}

atau menata karya-karya seni patung pada area pameran, khususnya yang berkenaan dengan pameran di luar ruangan.

2) Menyampaikan Materi

Penyampaian materi dilakukan dengan cara pemaparan secara langsung terhadap peserta pelatihan dengan media laptop dan infocus dan dilakukan di dalam ruangan. Teknik penyampaian materi dilakukan dengan cara dialog atau diskusi secara langsung antara peserta dan pemateri, khususnya tentang konsep dan teknik pembuatan karya seni patung dari jerami. Berkenaan dengan materi tentang cara membuat konsep karya seni patung, peserta dilibatkan secara langsung untuk melakukan riset ringan atau semacam wawancara terhadap tokoh masyarakat tentang nilai-nilai lokal setempat. Selanjutnya hasil wawancara tersebut divisualisasikan dalam bentuk sketsa yang kemudian diwujudkan dalam bentuk karya tiga dimensi berupa seni patung jerami.

3) Pelaksanaan Praktek

Pelaksanaan praktek pembuatan Hal| 49 karya seni patung jerami menggunakan metode demonstari, yaitu dengan cara memperagakan di depan peserta secara langsung mengenai tahapan-tahapan yang dilakukan dalam proses pembuatan karya seni patung, mulai dari proses pengenalan jenis bahan, pengenalan teknik, pembuatan kerangka, proses pembungkusan jerami, hingga proses finishing.

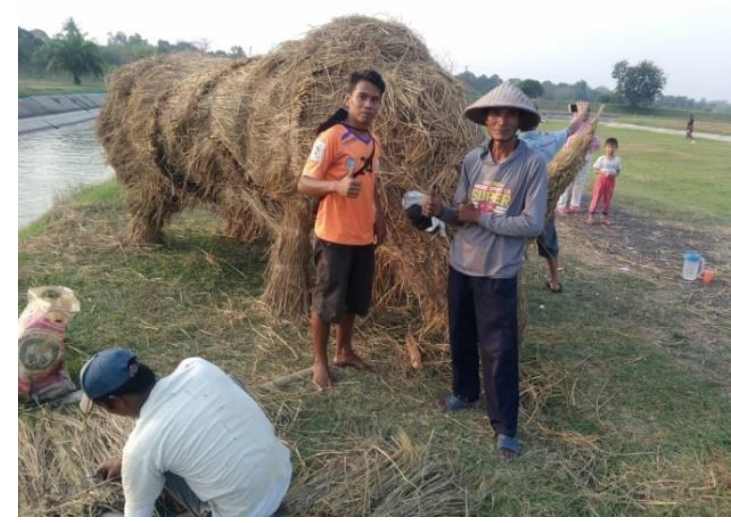

Gambar 1.

Pelaksanaan praktek pembuatan patung jerami. (Foto; Dokumentasi, Mukhsin Ilhaq, 2018) 


\section{Jurnal Batoboh, Vol 4, No1, Maret 2019 \\ Husni Mubarat, Mukhsin Ilhaq}

4). Metode Bimbingan

Metode ini dilakukan di mana peserta mulai melaksanakan praktek pembuatan patung jerami. Proses bimbingan dilakukan dengan cara kolektif, yang mana sebelumnya peserta telah dibagi menjadi beberapa kelompok. Bimbingan dilakukan pada aspek teknik yang terdiri dari proses pembuatan kerangka, pembentukan figur atau karakter patung yang dibuat. Selain itu proses bimbingan juga dilakukan pada aspek manajemen produksi yaitu pembagian kerja dalam proses penggarapan patung jerami, setiap peserta diberi tugas dan tanggung jawab masing-masing. Selanjutnya dilakukan juga proses bimbingan terhadap visualisasi konsep karya patung jerami itu sendiri.

Metode bimbingan juga dilakukan pada proses penyajian karya, baik bimbingan secara teoritik maupun secara praktek. Secara teoritik peserta pelatihan diminta untuk menata pameran berdasarkan materi tentang pameran yang telah disampaikan. Sedangkan bimbingan praktek, yaitu bimbingan secara langsung di lapangan dimana instruktur pelatihan memberikan Hal|50 pengarahan dan penjelasan bagaimana menata pameran yang sesuai dengan kaidah-kaidah seni rupa. Di samping itu karya yang ditata juga diupayakan dapat menarik perhatian masyarakat, sehingga dapat meningkatkan antusias masyarakat untuk datang pada acara festival jerami.

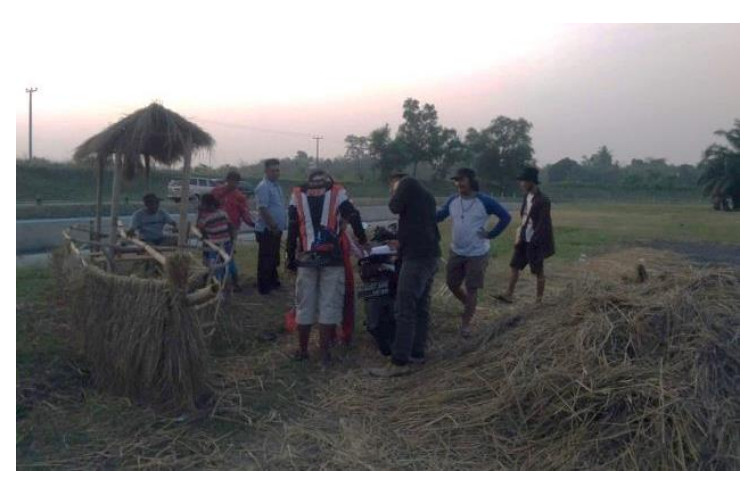

Gambar 2.

Pelaksanaan bimbingan pembuatan patung jerami.

(Foto; Dokumentasi, Mukhsin Ilhaq, 2018)

\section{Pembahasan dan Hasil Pengabdian}

\section{Sketsa Patung Jerami}

Sketsa, merupakan hasil dari visualisasi konsep atau ide gagasan yang digali oleh peserta pelatihan itu sendiri. Konsep yang dihadirkan tidak 


\section{Jurnal Batoboh, Vol 4, No1, Maret 2019 \\ Husni Mubarat, Mukhsin Ilhaq}

terlepas dari lingkungan, budaya, sosial, dan agama masyarakat sekitar. Jika diamati, secara garis besarnya konsep yang dihadir pada pelatihan pembuatan patung jerami tersebut lebih cenderung pada visualisasi kehidupan pertanian. Kehadiran konsep tersebut menggambarkan bahwa pertanian merupakan mata pencaharian utama bagi sebagian besar masyarakat di OKU Timur. Di sisi lain kosep tentang kehiduapn masyarakat petani juga memmiliki pesan dan makna yang ada di balik bentuk patung tersebut, baik pesan sosial, moral maupun pesan budaya. Berikut adalah beberapa sketsa yang dihasilkan:

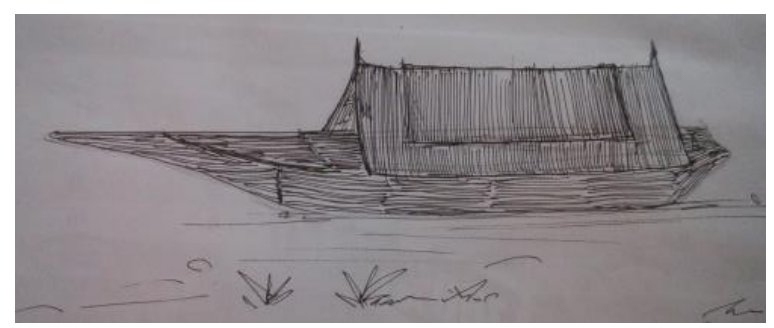

Gambar 3.

Sketsa perahu sebagai visualisasi alat transportasi yang pernah digunakan oleh masyarakat OKU Timur sebagai pengangkut hasil pertanian, baik dari sawah maupun ladang.

(Foto; Dokumentasi, Mukhsin Ilhaq, 2018)

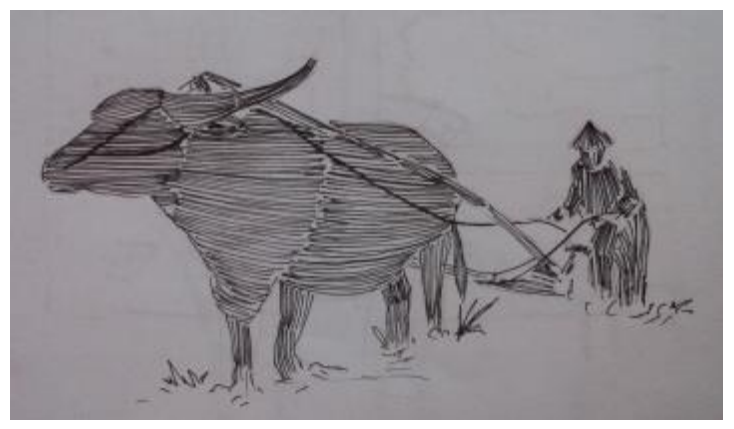

Gambar 4.

Sketsa visualisasi petani yang sedang membajak sawah dengan kerbau sebagai bentuk alat tradisional.

(Foto; Dokumentasi, Mukhsin Ilhaq, 2018)

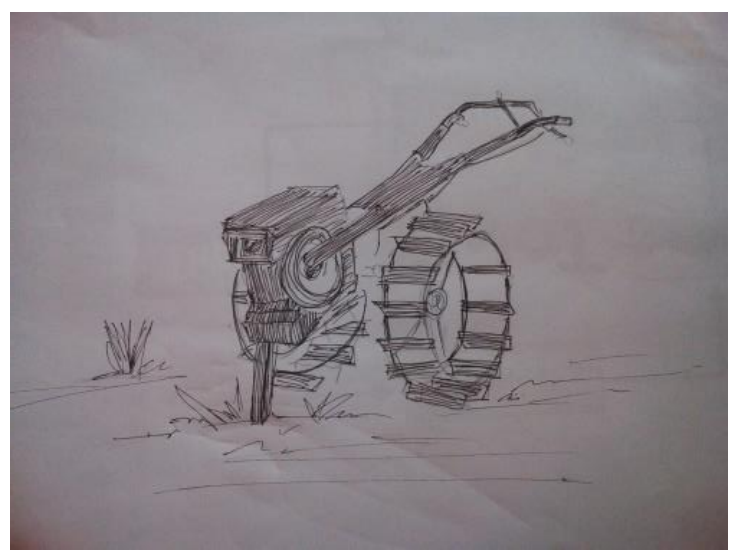

\section{Gambar 5.}

Sketsa traktor sebagai visualisasi transformasi alat pertanian modern.

(Foto; Dokumentasi, Mukhsin Ilhaq, 2018)

\section{Desain Layout Pameran patung Jerami}

Desain layout merupakan perencanaan bentuk dan suasana pameran yang akan dibuat. Perencanaan ini dirancang sesuai dengan konsep kegiatan acara yaitu Festival Jerami Sebiduk Sehaluan. Artinya konsep yang dibangun konsep 


\section{Jurnal Batoboh, Vol 4, No1, Maret 2019 \\ Husni Mubarat, Mukhsin Ilhaq}

yang dapat menggambar kebersamaan dan sikap gotongroyong dalam kehidupan masyarakat, sesuai dengan filosofi "Sebiduk Sehaluan" yaitu kebersamaan yang kokoh dalam kehidupan masyarakat. Sebelum dibuatkan dalam bentuk 3 dimensi, terlebih dahulu dibuatkan site plannya sesuai dengan area atau lokasi tempat diadakan pameran. Setelah site plan dikonsepkan baru kemudian dibuatkan layout pamerannya, layout tersebut dibuatkan dalam bentuk desain tiga dimensi. Proses tersebut dilakukan agar pada saat penyajian karya-karya patung jerami dapat dilakukan dengan efektif dan sesuai dengan konsep. Proses ini juga bertujuan untuk memberi pengalaman dan keterampilan bagi peserta pelatihan agar mendapatkan pengalaman dalam mengelola pameran dengan baik. Di samping itu desain lay out juga berfungsi untuk mempermudah peserta dalam menata pameran.

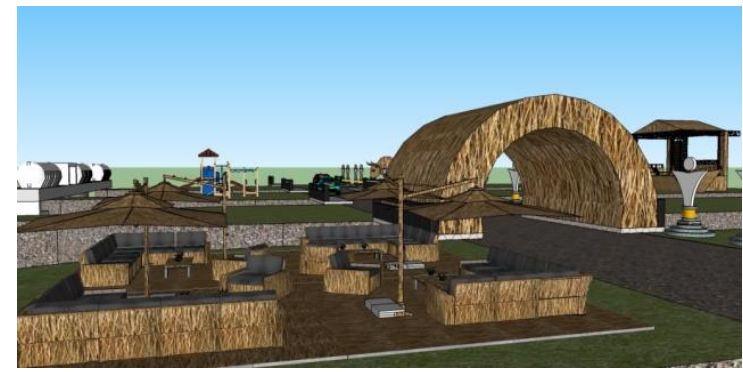

Hal 52

\section{Gambar 6}

Desain layout site plan pameran patung dan taman jerami.

(Desain; Dokumentasi, Bagus, 2018)

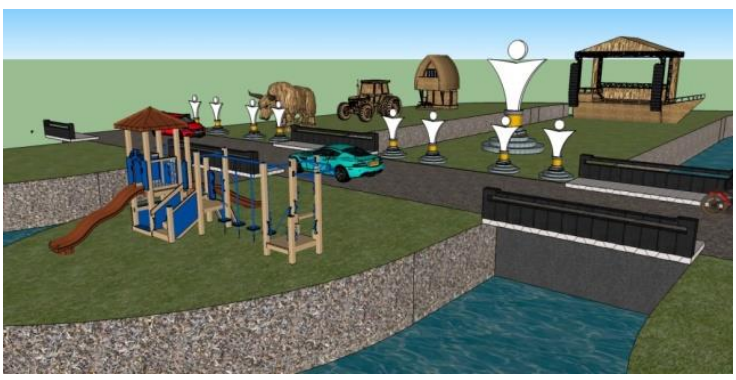

Gambar 7.

Desain layout site plan pameran patung dan taman jerami.

(Desain; Dokumentasi, Bagus, 2018)

$$
\text { Gambar } 8 .
$$

Desain layout site plan pameran patung dan

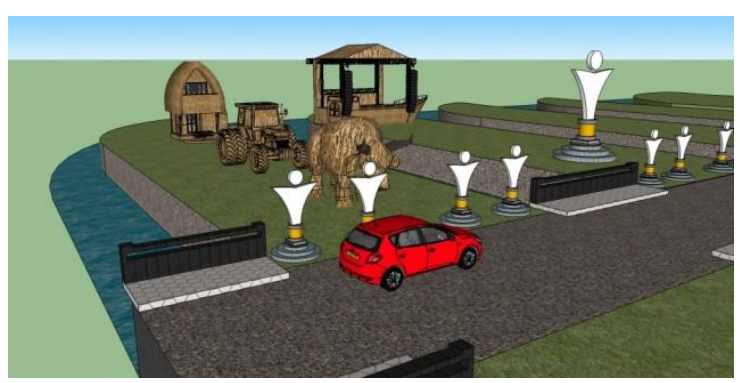

taman jerami.

(Desain; Dokumentasi, Bagus, 2018) 


\section{Jurnal Batoboh, Vol 4, No1, Maret 2019 \\ Husni Mubarat, Mukhsin Ilhaq}

\section{Pameran Patung Jerami}

Pameran adalah "suatu kegiatan penyajian karya seni rupa untuk dikomunikasikan sehingga dapat diapresiasi oleh masyarakat luas" (https://id.wikipedia.org/wiki/Pameran, diakses bulan maret 2018).

Kegiatan pameran patung jerami tidak terlepas dari upaya untuk mengkomunikasikan karya terhadap masyarakat luas. Kegiatan pameran pada pengabdian ini juga merupakan bagian dari kegiatan yang diutamakan dalam Festival Jerami Sebiduk Sehaluan. Patung-patung jerami dengan ukuran rata-rata antara 2-3 m disajikan dengan berbagai bentuk, mulai dari figur petani, bentuk buahbuahan (hasil pertanian), hingga karya patung dengan konsep budaya dan kearifan lokal.

Kegiatan pelatihan pameran tidak hanya terbatas pada penyajian dan penataan karya saja, namun dalam kegiatan ini peserta juga disuguhkan pengalaman bagaimana kerja tim dan manajemen dalam sebuah pameran. Oleh karena itu setiap tim yang sudah dibagi dituntut untuk bekerja sesuai dengan jobdesknya masing-masing.

Hal| 53

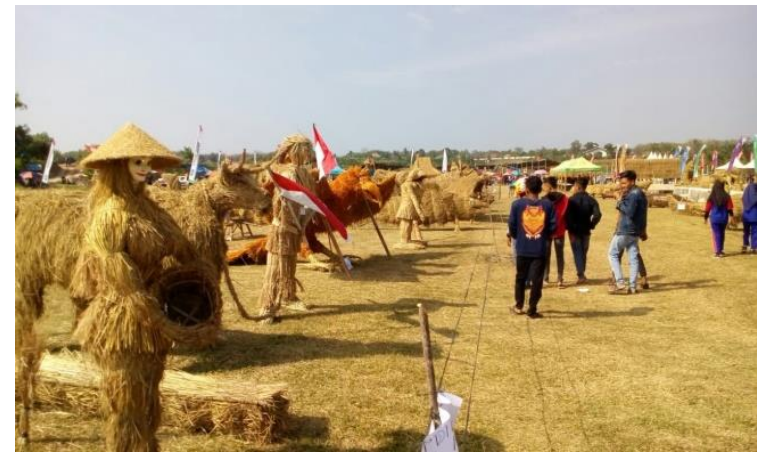

Gambar 9.

Suasana pameran patung jerami sebagai hasil karya masyarakat OKU Timur.

(Foto; Dokumentasi, Mukhsin Ilhaq, 2018)

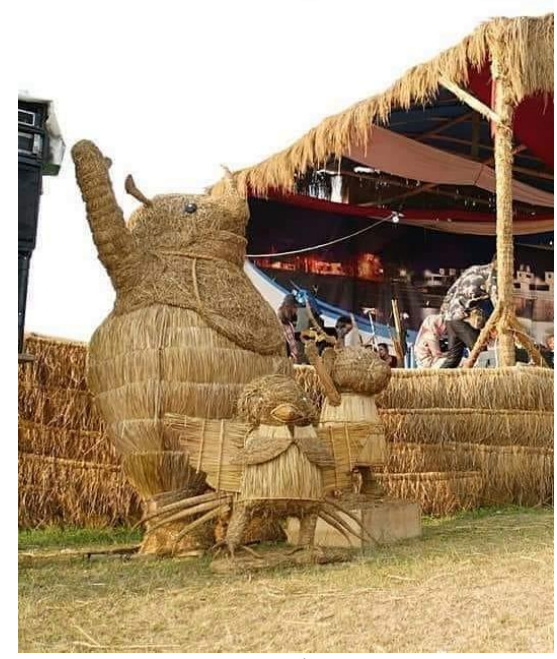

Gambar 10.

Salah satu karya patung jerami dengan tema maskot Asean Games. Karya ini sebagai bentuk dukungan terhadap acara asean games yang dilaksanakan di Palembang dan Jakarta.

(Foto; Dokumentasi, Mukhsin Ilhaq, 2018)

\section{Karya Patung Jerami}

Dalam kegiatan pelatihan ekplorasi jerami menjadi karya seni 


\section{Jurnal Batoboh, Vol 4, No1, Maret 2019 \\ Husni Mubarat, Mukhsin Ilhaq}

patung menghasilkan beberapa jenis

karya, di antaranya adalah:

a. Karya dengan konsep kearifan lokal

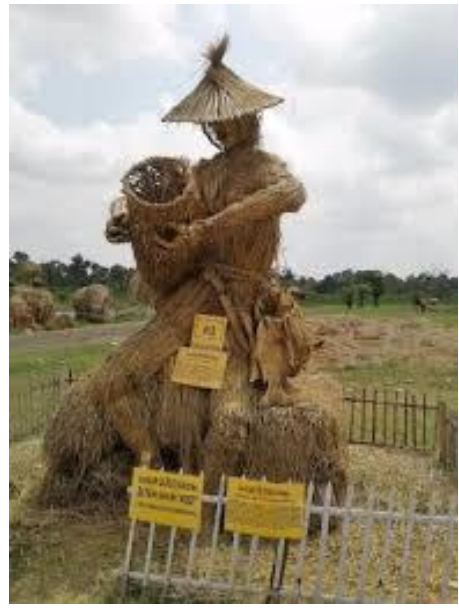

Gambar 11.

Karya patung jerami dengan konsep memasang lukah ikan. Menangkap ikan dengan lukah merupakan salah satu mata pencaharian masyarakat.

(Foto; Dokumentasi, Mukhsin Ilhaq, 2018)

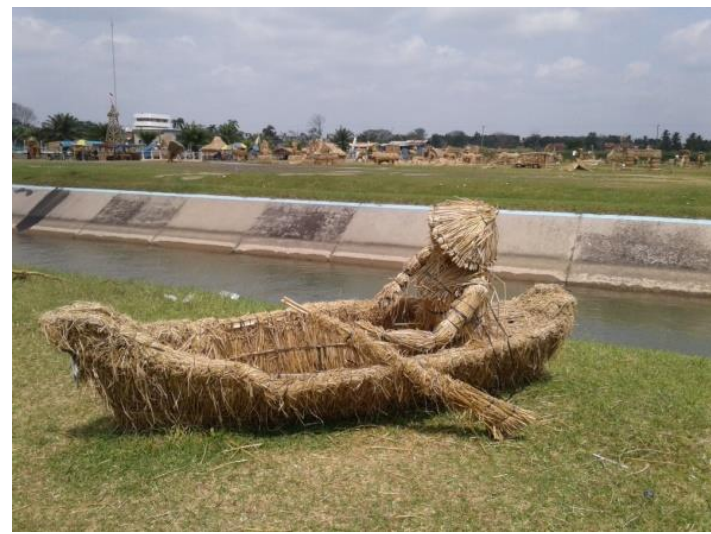

Gambar 12.

Karya patung jerami dengan konsep mendayung perahu. Perahu sebagai salah satu alat transportasi tradisional masyarakat $\mathrm{OKU}$

Timur pada masa lampau yang berfungsi untuk mengangkut hasil pertanian.

(Foto; Dokumentasi, Mukhsin Ilhaq, 2018)

\section{b. Karya dengan konsep pertanian}

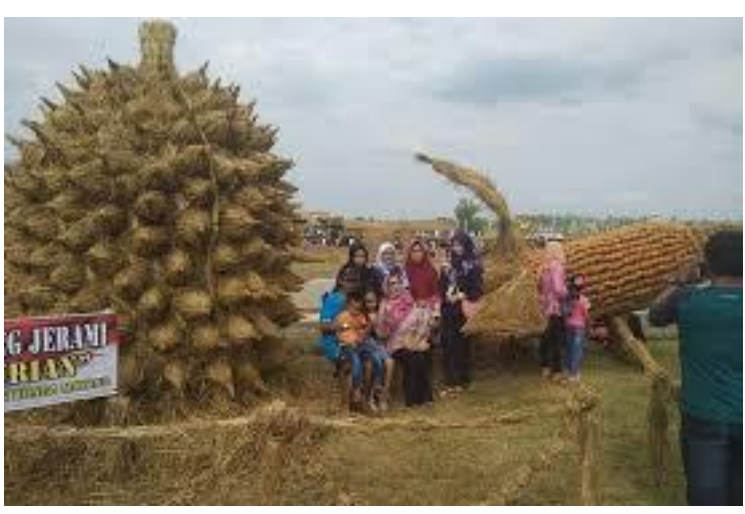

Hal| 54

\section{Gambar 13.}

Karya patung jerami dengan konsep hasil pertanian (durian dan jagung).

Foto; Dokumentasi, Mukhsin Ilhaq, 2018.

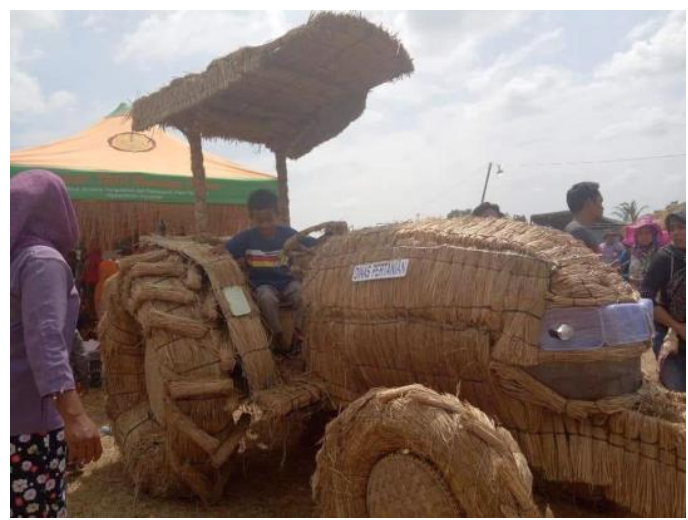

Gambar 14.

Karya patung jerami dengan konsep alat pertanian, yaitu traktor sebagai salah satu bentuk transformasi alat pertanian dari tradisi ke modern (teknologi).

Foto; Dokumentasi, Mukhsin Ilhaq, 2018. 


\section{Jurnal Batoboh, Vol 4, No1, Maret 2019 \\ Husni Mubarat, Mukhsin Ilhaq}

c. Karya dengan konsep hewan

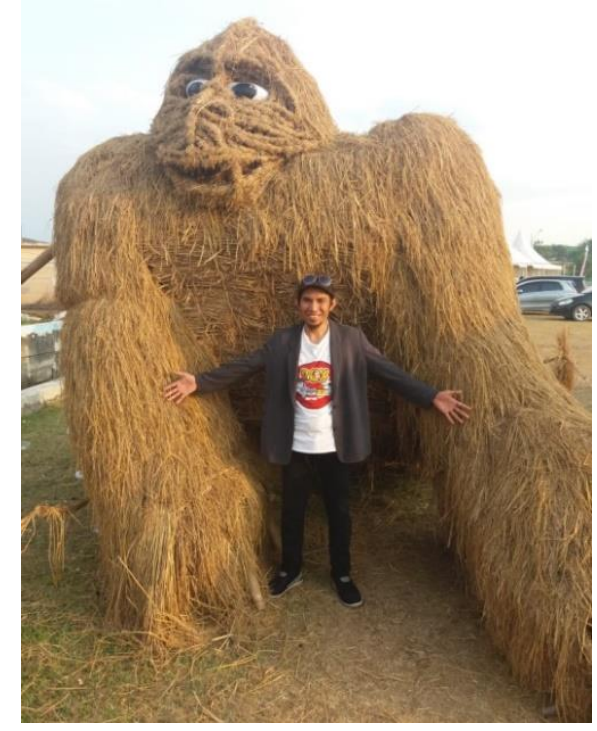

Gambar 15.

Karya patung jerami dengan karakter hewan Gorila. Salah satu karya jerami terfavorit. (Foto; Dokumentasi, Mukhsin Ilhaq, 2018)

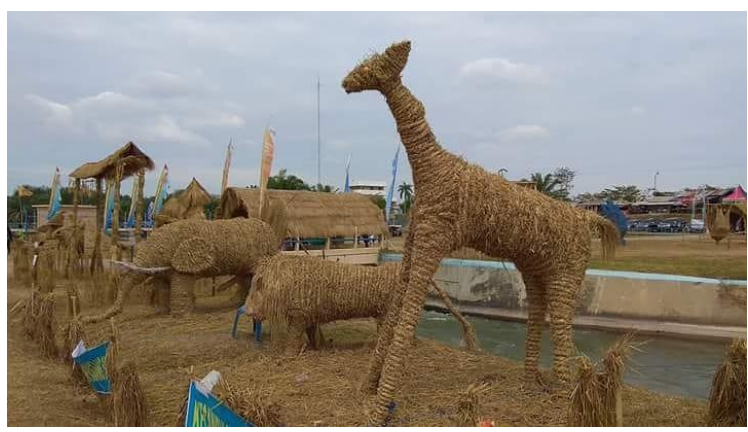

Gambar 16.

Karya patung jerami dengan beberapa karakter hewan seperti Jerapah, Singa dan Gajah. (Foto; Dokumentasi, Mukhsin Ilhaq, 2018)

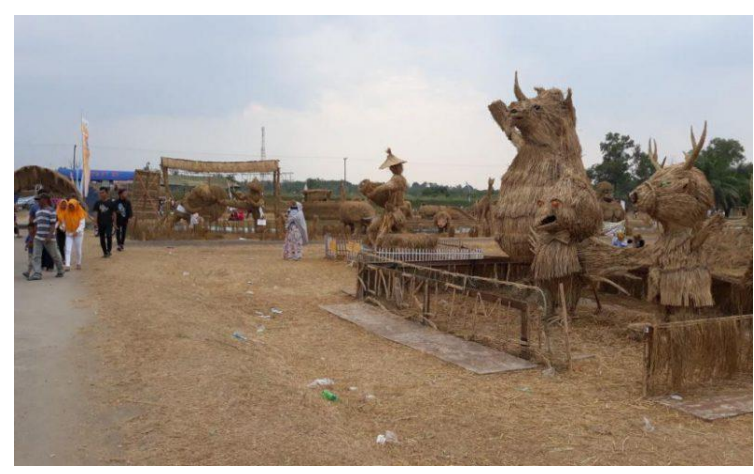

Gambar 17.

Karya patung jerami dengan beberapa karakter hewan badak, rusa dan burung (maskot Asean

Games 2018). Karya ini sebagai wujud dukungan terhadap Asean Games.

(Foto; Dokumentasi, Mukhsin Ilhaq, 2018)

\section{SIMPULAN}

Pelatihan pembuatan patung dari jerami merupakan suatu proses kreativitas masyarkat. Selama kegiatan pelatihan pembuatan patung dapat dilihat bahwa setiap manusia pada dasarnya memiliki jiwa dan kepekaan terhadap sebuah karya seni, sehingga hampir semua peserta yang terlibat memiliki antusias yang tinggi selama mengikuti pelatihan pembuatan patung jerami. Tentunya karya seni patung yang dihasilkan memiliki kualitas yang berbeda, karena disadari bahwa setiap peserta memiliki kemampuan yang berbeda untuk mengekspresikan karya 


\section{Jurnal Batoboh, Vol 4, No1, Maret 2019 \\ Husni Mubarat, Mukhsin Ilhaq}

seni, baik dari teknis maupun dari segi konsep.

Dari materi yang disampaikan selama pelatihan dapat disimpulkan berdasarkan pemaparan materi baik dari pembuata sketsa, teknik (tahapan dan proses pembuatan patung) hingga mengkonsepkan karya patung jerami.

Dari pembuatan sketsa hasil yang dapat disimpulkan bahwa peserta mendapat pengalaman dan pengetahuan tantang teknik pembuatan sketsa, tetapi tidak semua peserta memiliki kemampuan untuk membuat sketsa, karena ini tentu berkaitan dengan latar belakang pendidikannya masing-masing. Namun di balik itu, tidak sedikit pula peserta yang memiliki kemampuan untuk membuat sketsa, karena memiliki bakat secara alamiah.

Dari segi tahapan prosesnya dapat disimpulkan bahwa peserta dapat memahami dan mengaplikasi apa yang disampaikan oleh instruktur, baik dalam pembuatan sambungan kerangka, pembentukan objek karya, maupun proses pemasangan jerami pada kerangka. Pada proses pemasangan jerami pada kerangka patung yang sudah dibuat dilakukan dengan berbagai teknik, dari teknik Hal|56 tempel, anyam hingga dibuatkan seperti gumpalan-gumpalan. Sebagaian teknik pemasangan jerami dapat dikatak bersifat improvisasi atau lebih menyesuaikan dengan bentuk dan kerangka serta karakter karya yang diinginkan.

Pada aspek konsep, dapat disimpulkan bahwa tidak semua peserta yang dapat memahaminya, karena sebagian peserta hanya mengutamakan aspek bentuk. Tetapi secara keseluruhan karya-karya yang dihasilkan sesungguhnya sudah mengandung konsep yang dirumuskan oleh konseptor yaitu karya-karya yang menggambarkan tentang kehidupan petani. Di satu sisi memang ada beberapa karya yang konseptualnya tidak terkait dengan apa yang dirumuskan oleh konseptor, seperti patung jerapah, gajah, singa dan lainlain. Akan tetapi dalam konteks festival jerami karya tersebut menjadi bagian 


\section{Jurnal Batoboh, Vol 4, No1, Maret 2019 \\ Husni Mubarat, Mukhsin Ilhaq}

yang cukup menarik perhatian bagi pengunjung, seperti patung Gorila yang kemudian menjadi karya terfavorit.

Dari aspek-aspek yang telah disimpulkan dapat dikatakan bahwa selama proses pelatihan pembuatan patung jerami, kegiatan ini merupakan pengamalan baru bagi masyarakat OKU Timur baik eksplorasi jerami maupun kegiatan festivalnya, bahkan untuk di Sumatera festival patung jerami ini merupakan yang pertama kali diadakan dan khususnya di Sumatera Selatan. Melalui kegiatan ini diharapkan kesenian, khususnya seni rupa (seni patung) mendapat apresiasi di tengah masyarakat sehingga seni rupa dapat tumbuh di tengah-tengah kehidupan masyarakat, dan tentunya diharapkan dapat menumbuhkan nilai budaya dan ekonomi bagi masyarakat. Hal| 57

\section{KEPUSTAKAAN}

Irawan, Deddy ed., (2017). Paradigma Pendidikan Seni. Yogyakarta: Thafa Media.

Kartika, Dharsono Sony. (2004). Seni Rupa Modern. Bandung: Rekayasa Sains.

Ranjabar, Jacobus. (2006). Sistem Sosial Budaya Indonesia Suatu Pengantar. Bogor: Ghalia Indonesia.

https://id.wikipedia.org/wiki/pameran, diakses bulan maret 2018 . 